\title{
Role of smooth muscle in intestinal inflammation
}

\author{
STEPHEN M COLLINS MD FRCPC, ISLAM KHAN PhD, BRUCE VALLANCE BSc, \\ CORY HOGABOAM PhD, GIOVANNI BARBARA MD
}

SM Collins, I Khan, B Vallance, C Hogaboam, G BarBARA. Role of smooth muscle in intestinal inflammation. Can J Gastroenterol 1996;10(4):249-253. The notion that smooth muscle function is altered in inflammation is prompted by clinical observations of altered motility in patients with inflammatory bowel disease (IBD). While altered motility may reflect inflammationinduced changes in intrinsic or extrinsic nerves to the gut, changes in gut hormone release and changes in muscle function, recent studies have provided in vitro evidence of altered muscle contractility in muscle resected from patients with ulcerative colitis or Crohn's disease. In addition, the observation that smooth muscle cells are more numerous and prominent in the strictured bowel of IBD patients compared with controls suggests that inflammation may alter the growth of intestinal smooth muscle. Thus, inflammation is associated with changes in smooth muscle growth and contractility that, in turn, contribute to important symptoms of IBD including diarrhea (from altered motility) and pain (via either altered motility or stricture formation). The involvement of smooth muscle in this context may be as an innocent bystander, where cells and products of the inflammatory process induce alterations in muscle contractility and growth. However, it is likely that intestinal muscle cells play a more active role in the inflammatory process via the elaboration of mediators and trophic factors, including cytokines, and via the production of collagen. The concept of muscle cells as active participants in the intestinal inflammatory process is a new concept that is under intense study. This report summarizes current knowledge as it relates to these two aspects of altered muscle function (growth and contractility) in the inflamed intestine, and will focus on mechanisms underlying these changes, based on data obtained from animal models of intestinal inflammation.

Key Words: Cytokines, Diarrhea, Inflammation, Lymphocytes, Smooth muscle

\section{Rôle du muscle lisse dans l'inflammation intestinale}

RÉSUMÉ : L'hypothèse selon laquelle la fonction du muscle lisse est altérée en présence d'inflammation découle d'observations cliniques portant sur les anomalies de la motilité chez des patients atteints de maladies inflammatoires de l'intestin (MII). Les anomalies de la motilité peuvent être le reflet de changements provoqués par l'inflammation dans les nerfs intrinsèques ou extrinsèques qui innervent l'intestin, de changements du taux de libération hormonale dans l'intestin et de changements de la fonction musculaire. De récentes études ont mis au jour des anomalies in vitro de la contractilité musculaire dans les muscles provenant de patients atteints de colite ulcéreuse ou de maladie de Crohn. De plus, l'observation de cellules musculaires lisses en plus grand nombre et prépondérantes dans l'intestin rétréci des patients atteints de MII, en comparaison avec des témoins, donne à penser que l'inflammation peut modifier la croissance du muscle lisse intestinal. Ainsi, l'inflammation est associée à des changements de la croissance du muscle lisse et de la contractilité, qui en retour contribuent à l'apparition des importants symptômes des MII, notamment la diarrhée (due à l'altération de la motilité) et la douleur (due soit à l'altération de la motilité ou à la formation de strictures). L'atteinte musculaire lisse dans ce contexte peut être simplement marginale, alors que les cellules et les produits du processus inflammatoire provoquent des altérations de la contractilité et de la croissance musculaire. Toutefois, les cellules musculaires lisses jouent probablement un rôle plus actif dans le processus inflammatoire par l'élaboration de médiateurs et de facteurs trophiques, y compris les cytokines et par la production de collagène. Le concept selon lequel les cellules musculaires participent activement au processus inflammatoire intestinal est nouveau et fait l'objet d'études approfondies. Ce rapport résume les connaissances accumulées à ce jour au sujet de ces deux aspects de l'altération de la fonction musculaire (croissance et contractilité) dans l'intestin enflammé et s'attardera sur les mécanismes sous-jacents de ces anomalies selon les données tirées d'expériences sur l'inflammation intestinale menées chez les animaux.

Intestinal Diseases Research Programme, McMaster University Medical Centre, Hamilton, Ontario

Correspondence and reprints: Dr Stephen M Collins, Room 4W8, GI Division, McMaster University Medical Centre, Hamilton, Ontario L8N 325. Telephone 905-521-2100 ext 5255, fax 905-521-4958, e-mail scollins@fhs.mcmaster.ca

This paper was presented at the Basic Research and Clinical Implications in IBD meeting, April 6 to 9, 1994, held in Victoria, British Columbia. This paper has also been published in Sutherland LR, et al, eds. Inflammatory Bowel Disease: Basic Research, Clinical Implications and Trends in Therapy. Boston, Dordrecht and London: Kluwer Academic Publishers, 1994 
Tntestinal inflammation not only produces mucosal damage but also alters gut physiology. Traditionally this has been studied in the context of epithelial cell function, but it is becoming increasingly apparent that deeper tissues of the gut wall are also involved and include the neuromotor apparatus, namely enteric nerves, interstitial cells of Cajal and smooth muscle cells. This review focuses on changes that occur in smooth muscle following mucosal inflammation in the gut.

\section{CHANGES IN SMOOTH MUSCLE CONTRACTION}

Regional differences in muscle responses to inflammation: The observation that active ulcerative colitis is accompanied by a reduction in motor activity in the distal colon (1-3) suggests that the contractility of colonic smooth muscle may be impaired as a result of inflammation. This has been confirmed in an in vitro study of human colonic circular muscle in which contraction induced by either bethanechol or potassium chloride was significantly reduced compared with muscle obtained from patients without inflammatory bowel disease (IBD) (4), suggesting that the underlying mechanism is located at the postreceptor level in the excitationcontraction coupling of the muscle cell. Similar observations have been made in animal models of colitis (5).

In our study (5), a similar decrease in colonic smooth muscle contractility was observed in colitis induced by chemical injury (acetic acid or trinitrobenzene sulphonic acid [TNB]), as well as by infection (Trichinella spiralis). These results also illustrate that inflammation-induced changes in smooth muscle are nonspecific in that they do not appear to be influenced by the manner in which colitis is induced.

There are no reports of small bowel motility in Crohn's disease patients upon which to speculate about the nature of any underlying change in muscle contraction. However, an in vitro study from this laboratory demonstrated that both circular and longitudinal muscles from the inflamed ileum of patients with Crohn's disease exhibited increased contractility compared with muscle from patients without IBD (6). The increased contractility occurred following stimulation with either carbamylcholine or histamine, suggesting that the underlying mechanism was not exclusively at the receptor level, although differences in the dose-response relationships between control and inflamed tissues suggested that some alterations in the ligand-recognition properties of receptors may contribute to the observed changes.

Taken in conjunction with the results obtained in the inflamed human colon, the results imply that the nature of inflammation-induced changes in intestinal muscle is region-specific. This is supported by results from animal studies in which inflammation induced in either the small intestine or colon by the same stimulus ( $T$ spiralis) resulted in a similar profile of altered contractility; there was increased tension development by muscle from the inflamed small intestine (7) and a reduction in tension development by muscle from the inflamed colon (5).
Mechanisms underlying altered muscle contraction in the inflamed intestine: Information regarding the mechanisms underlying altered smooth muscle function in the inflamed intestine is primarily derived from studies of animal models of acute intestinal inflammation. It should be emphasized that these models are not of IBD per se, but are paradigms for testing the impact of inflammation on tissue function and to explore underlying mechanisms. This laboratory has focused its efforts on primary nematode infections of rodents since these models have been in longstanding use for the study of immunophysiological interactions in the gut (8) and there is extensive literature regarding the immunological responses of the rodent host to nematode infection.

In keeping with the postulate that the mechanisms underlying changes in smooth muscle contractility in the inflamed intestine are, for the most part, receptor-independent is the finding of suppressed sodium pump activity in muscle from the inflamed jejunum of $T$ spiralis-infected rats (9). In that study, we showed that ouabain-sensitive ${ }^{86} \mathrm{Rb}$ uptake by longitudinal muscle was reduced by more than $80 \%$ compared with control, and that this was accompanied by a corresponding decrease in activity PNPPase ( $\mathrm{p}$-nitrophenylphosphatase) activity - an enzyme marker of sodium pump activity. The molecular mechanism underlying this change was also explored, and suppression of sodium pump activity likely occurs at the level of gene transcription of the $\alpha-I$ isoform of the sodium pump protein (10). Because this pump is electrogenic, its suppression during inflammation would lead to hyperexcitability of the muscle as membrane potential would be reduced to a level closer to the threshold for contraction. However, it is plausible that the increased contractility of muscle in the inflamed gut is multi-factorial because others have shown in this model that there is an increase in the contractile protein content of muscle (11).

Trophic changes in muscle from the inflamed intestine: In Crohn's disease strictures, there is profound thickening of both the muscularis mucosae and propria and muscle cell proliferation $(12,13)$. Furthermore, there are preliminary data suggesting that intestinal muscle cells from IBD patients exhibit altered growth patterns compared with controls (14). The mechanisms underlying the hyperplasia of smooth muscle in the inflamed intestine remain to be determined but studies in animal models indicate that both hyperplasia and hypertrophy of the muscularis externa occur during intestinal inflammation (15). Subsequent studies have indicated that these trophic changes are determined by different mediators potentially involved in the inflammatory response. For example, interleukin-1 $\beta$ (IL-1 $\beta$ ) and platelet-derived growth factor have calcium-dependent mitogenic effects on human (16) and rodent intestinal smooth muscle growth in vitro. Furthermore, in a similar system, we have preliminary data suggesting that the constitutive release of nitric oxide modulates intestinal smooth muscle proliferation. Studies are ongoing to explore the relative impact of pro-inflammatory and anti-inflammatory substances to intestinal smooth muscle proliferation.

Inflammatory basis for altered muscle contraction and 
growth: Changes in muscle contraction are absent from corticosteroid-treated, nematode-infected rats in whom the inflammatory response has been suppressed (17). In addition, the changes are absent from congenitally athymic rats following $T$ spiralis infection (18). Moreover, the changes in muscle contraction are restored following successful reconstitution of $\mathrm{T}$ lymphocyte function before infection (18). These findings, taken in conjunction with the demonstration of $\mathrm{T}$ cell infiltration of the muscle layer within the first $48 \mathrm{~h}$ of infection (19), support the hypothesis that the increased contraction of smooth muscle from the inflamed intestine of $T$ spiralis-infected rats is T lymphocyte-dependent. Similar observations have been made in nematode-infected mice (20). In addition, it is well known that certain inbred mouse strains develop a greater or more effective immune responsiveness to nematode infections than other strains (2123). Our preliminary studies using inbred mice indicate that changes in muscle contractility may also be genetically determined and that there is a positive correlation between the increased contractility of muscle and the ability of the animal to expel the parasite from the gut. This correlation is potentially important because the process of worm expulsion is also $\mathrm{T}$ lymphocyte-dependent and a series of studies have indicated that $\mathrm{CD} 4^{+}$helper cells are likely responsible (24). This has prompted our ongoing investigation of the role of $\mathrm{CD}^{+}$ cell subpopulations and their cytokine products as mediators of the observed changes in muscle contraction.

Space prohibits an exhaustive review of factors that affect intestinal smooth muscle growth but suffice it to say that the phenomenon of intestinal smooth muscle proliferation during inflammation is mediated by immune cells and the mediators they produce. For example, the hyperplasia of intestinal muscle in $T$ spiralis-infected rats is $T$ lymphocytedependent (25). Whether this reflects a direct or indirect interaction between lymphocytes and muscle cells is currently being investigated. Furthermore, during TNB-colitis in rats (another model of intestinal inflammation characterized by profound smooth muscle hyperplasia), the presence of proliferating smooth muscle cells in the external muscle layers was abolished by oral administration of a nitric oxide synthase inhibitor (26). Although its source(s) in the muscle layer is currently speculative, nitric oxide also appears to play a role in smooth muscle hyperplasia during intestinal inflammation. Studies are ongoing into other potential immune mechanisms of regulation of smooth muscle growth during inflammation.

\section{MUSCLE CELLS AS ACTIVE PARTICIPANTS IN INTESTINAL INFLAMMATION}

Collagen production by intestinal muscle cells: Several observations prompt consideration of an active role by muscle in the inflammatory process in the gut. In IBD, ultrastructural studies have shown changes in muscle suggestive of active protein synthesis (27). In addition, some muscle cells are surrounded by collagen and it is known that human intestinal smooth muscle cells in culture synthesize and secrete collagen types I, III and V (28). Transforming growth factor- beta (TGF- $\beta$ ) stimulates collagen synthesis by muscle cells (29), and preliminary studies from this laboratory indicate that TGF- $\beta$ induced stimulation of collagen synthesis by muscle cells involves the influx of extracellular calcium through verapamil-sensitive channels.

Collagen synthesis by muscle is not only clinically important in the context of stricture formation, but also illustrates two important concepts. First, muscle cells engage in noncontractile activities that contribute to the inflammatory process, and second, muscle cells are receptive to immune modulation, as illustrated by their responsiveness to the cytokine TGF- $\beta$. Further examples of these concepts will be discussed.

Cytokine production by muscle cells: A study by Kao et al (30) showed that inflammatory mediator production in the gut is not restricted to cells of the mucosa and lamina propria; these authors showed that there was exaggerated production of prostaglandin $\mathrm{E}_{2}\left(\mathrm{PGE}_{2}\right)$ in the muscularis externa of the colon, inflamed following the administration of formalin and immune complexes to rabbits. In the absence of a discernible inflammatory cell infiltrate in the muscularis externa, the production of $\mathrm{PGE}_{2}$ was attributed to muscle cells, which have been known for some time to produce prostaglandins.

Recent work has extended this observation to address cytokine production by muscle cells (30). Although the concept of cytokine production by cells other than those of bone marrow origin is not new, the application of this to intestinal muscle is novel. Two observations in the nematode-infected rat have prompted this investigation. First, we have observed ultrastructural changes in muscle cells of the inflamed rat jejunum that are similar to those observed in muscle from patients with IBD. These include enhancement of the Golgi apparatus and prominence of the rough endoplasmic reticulum suggestive of active protein synthesis. Second, we have found evidence of cytokine gene expression and protein production in the muscularis externa of the inflamed jejunum following $T$ spiralis infection in rats (31). Specifically, we have shown that there is constitutive expression of IL- $1 \beta$ mRNA and protein in the muscularis externa, and that this increases within $12 \mathrm{~h}$ of infection. The increased expression of IL-1 $\beta$ is followed by the expression of other cytokines, including IL-6 and tumour necrosis factor-alpha (TNF- $\alpha$ ). These observations prompted an evaluation of the ability of intestinal muscle cells to express cytokine genes and secrete cytokine proteins. Since the expression of IL- $1 \beta$ was enhanced earliest in the muscularis externa, we suspected that this cytokine might be the stimulus for the induction of other cytokine genes in smooth muscle. Our results to date provide clear evidence that muscle cells express cytokine genes and secrete the corresponding proteins. First, IL-1 $\beta$ induces its own gene expression in muscle cells and this is accompanied by protein production (32). Second, IL-1 $\beta$ also induces IL- 6 gene expression and this is also accompanied by protein secretion (33). Ongoing studies are evaluating the ability of muscle cells to produce other cytokines including TNF- $\alpha$ and TGF- $\beta$.

Major histocompatibility complex on smooth muscle cells: 
We have already demonstrated lymphocytic infiltration of the muscularis externa in the intestine of $T$ spiralis-infected rats, and we have also shown the expression of major histocompatibility complex (MHC) II in this tissue during infection (19). The precise localization of the MHC II complexes has yet to be determined. Similar observations have been made in T spiralis-infected mice; in addition to MHC II expression, we have documented the expression of the adhesion molecule ICAM-1 in the muscularis externa of infected mice (34). The functional significance of these findings remain to be determined. Parallel studies using cultured muscle cells isolated from the mouse intestine have shown that MHC II and ICAM-1 expression can be induced following exposure to interferon-gamma (IFN- $\gamma$ ) and the IFN- $\gamma$ effect was potentiated by TNF- $\alpha$ or IL-1 $\beta$ (34). These findings raise the possibility that muscle may contribute to immune activation via MHC II-linked antigen presentation, and this speculation is based upon the observation that antigen presentation has been demonstrated in a variety of cell types including human myoblasts (35) and vascular smooth muscle (36). It is possible that increased intestinal permeability as well as changes in vascular permeability in the gut wall during nematode infection permit access of luminal as well as parasite antigens to the muscularis externa (37). Cytokines released by lymphocytes that infiltrate the muscle layer may induce MHC II and ICAM-1 expression by muscle cells. If this is accompanied by antigen processing and presentation, together with the elaboration of co-stimulatory factors such as IL-1 or IL-8, lymphocyte activation may occur followed by clonal selection of the T cell population. Current research is

\section{REFERENCES}

1. Rao SSC, Read NW, Brown C, Bruce C, Holdsworth CD. Studies on the mechanism of bowel disturbance in ulcerative colitis. Gastroenterology 1987;93:934-40.

2. Kern FJ, Almy TP, Abbot FK, Bogdonoff MD. Motility of the distal colon in nonspecific ulcerative colitis. Gastroenterology 1951;19:492-503.

3. Snape WJ, Matarazzo SA, Cohen S. Abnormal gastrocolonic response in patients with ulcerative colitis. Gut 1980;21:392-6.

4. Snape WJ, Williams R, Hyman PE. Defect in colonic muscle contraction in patients with ulcerative colitis. Am J Physiol 1991;261:G987-91.

5. Grossi L, McHugh K, Collins SM. On the specificity of altered muscle function in experimental colitis in rats. Gastroenterology 1993;104:1049-56.

6. Vermillion DL, Huizinga JD, Riddell RH, Collins SM. Altered small intestinal smooth muscle function in Crohn's disease. Gastroenterology 1993;104:1692-700.

7. Vermillion DL, Collins SM. Increased responsiveness of jejunal longitudinal muscle in trichinella-infected rats. Am J Physiol 1988;254:G124-9.

8. Russell DA, Castro GA. Physiology of the gastrointestinal tract in the parasitized host. In: Johnson LR, ed. Physiology of the Gastrointestinal Tract, 2nd edn. New York: Raven Press, 1987:1749-80.

9. Muller MJ, Huizinga JD, Collins SM. Altered smooth muscle contraction and sodium pump activity in the inflamed rat intestine. Am J Physiol 1989;257:G570-7.

10. Khan I, Collins SM. Altered sodium pump gene expression in the inflamed intestine of the nematode-infected rat. Am J Physiol 1993;264:G1160-8.

11. Bowers RL, Castro GA, Lai M, Harari Y, Weisbrodt NW. Actin mRNA expression in intestinal smooth muscle of rats infected with Trichinella spiralis. Gastroenterology 1990;99:1236. (Abst)

12. Graham MF, Diegelmann RF, Elson CO, et al. Collagen content and evaluating whether smooth muscle cells are capable of activating lymphocytes via antigen presentation.

\section{CLINICAL SIGNIFICANCE}

The implications of inflammation-induced changes in smooth muscle contractility and growth are obvious in the context of symptom generation in intestinal inflammatory conditions including IBD. The clinical consequences of a more active role for muscle cells in immune activation are perhaps more subtle but are nevertheless worthy of consideration. For example, IBD in remission is often accompanied by symptoms suggestive of irritable bowel syndrome (38) and persistent functional abnormalities in the bowel $(1,39)$. These abnormalities persist in the face of a normal appearance of the overlying mucosa. It is possible that the mucosal injury and inflammation that characterize active IBD induce changes in the muscularis externa that persist following resolution of the mucosal changes; recent data from animal studies support this hypothesis (40). These persistent changes in the neuromuscular layers could be maintained through the elaboration of cytokines and other mediators by muscle cells. This scenario requires that cytokines are able to alter the physiology of neuromuscular tissues and evidence of this has already been obtained $(41,42)$.

ACKNOWLEDGEMENTS: This work was supported by a grant from the Medical Research Council (MRC) of Canada to Dr SM Collins. Dr CM Hogaboam is a recipient of an MRC Fellowship.

types in the intestinal strictures of Crohn's disease. Gastroenterology 1988;94:257-65.

13. Dvorak AM, Connell AB, Dickersin GR. Crohn's disease, a scanning electron microscopic study. Hum Pathol 1979;10:165-77.

14. Shah M, Willey A, Graham MP. Inflammatory bowel disease induces changes in the in vitro phenotype of human intestinal muscle cells. Gastroenterology 1993;104:A779. (Abst)

15. Blennerhassett MG, Vignjevic P, Vermillion DL, Collins SM. Inflammation causes hyperplasia and hypertrophy in smooth muscle of rat small intestine. Am J Physiol 1992;262:G1041-6.

16. Scheinfeld BA, Collins SM, Blennerhassett MG. Verapamil inhibits interleukin-1 $\beta$-mediated hyperplasia of human intestinal smooth muscle. Gastroenterology 1994;106:A768. (Abst)

17. Marzio L, Blennerhassett P, Chiverton S, Vermillion DL, Langer J, Collins SM. Altered smooth muscle function in worm-free gut regions of trichinella-infected rats. Am J Physiol 1990;259:G306-13.

18. Vermillion DL, Ernst PB, Collins SM. T-lymphocyte modulation of intestinal muscle function in the trichinella-infected rat. Gastroenterology 1991;101:31-8.

19. Dzwonkowksi P, Stead RH, Blennerhassett MG, Collins SM. Induction of class II major histocompatibility complex (MHC II) in enteric smooth muscle. Gastroenterology 1991;100:A577. (Abst)

20. Vallance BA, Blennerhassett PA, Collins SM. T lymphocyte dependence of persistent intestinal muscle function post infection by Trichinella spiralis in the mouse. Gastroenterology 1994;106:A1054. (Abst)

21. Else KJ, Hultner L, Grencis RK. Cellular immune responses to the murine nematode parasite Trichuris muris. II. Differential induction of Th-cell subsets in resistant versus susceptible mice. Immunology 1992; 75:232-7.

22. Else KJ, Grencis RK. Cellular immune responses to the murine nematode parasite Trichuris muris. I. Differential cytokine production during acute or chronic infection. Immunology 1991;72:508-13.

23. Zhu DH, Bell RG. IL-2 production, IL-2 receptor expression, and IL-2 responsiveness of spleen and mesenteric lymph node cells from 
inbred mice infected with Trichinella spiralis. J Immunol 1989;142:3262-7.

24. Wakelin D. Allergic inflammation as a hypothesis for the expulsion of worms from tissues. Parasitol Today 1993;9:115-6.

25. Blennerhassett MG, Vignjevic P, Vermillion DL, Ernst PB, Collins SM. Intestinal inflammation induces T-lymphocyte-dependent hyperplasia of jejunal smooth muscle. Gastroenterology 1990;98:A328. (Abst)

26. Hogaboam CM, Jacobson K, Collins SM, Blennerhassett MG. The selective beneficial effects of nitric oxide inhibition in experimental colitis. Am J Physiol 1995;268:G673-84.

27. Dvorak AM, Osage JE, Monohan RA, Dickersin GR. Crohn's disease: transmission electron microscopic studies. III Target tissues. Proliferation of and injury to smooth muscle and the autonomic nervous system. Hum Pathol 1980;11:620-34.

28. Graham MF, Drucker DE, Diegelmann RF, Elson CO. Collagen synthesis by human intestinal smooth muscle cells in culture. Gastroenterology 1987;92:400-5.

29. Graham MF, Bryson GR, Diegelmann RF. Transforming growth factor beta 1 selectively augments collagen synthesis by human intestinal smooth muscle cells. Gastroenterology 1990;99:447-53.

30. Kao HW, Zipser RD. Exaggerated prostaglandin production by colonic smooth muscle in rabbit colitis. Dig Dis Sci 1988;33:697-704.

31. Khan I, Blennerhassett P, Gauldie J, Collins SM. Cytokine mRNA profile in smooth muscle from the inflamed intestine of the nematode-infected rat. Gastroenterology 1992;102:A645. (Abst)

32. Khan I, Kataeva G, Blennerhassett MG, Collins SM. Auto-induction of interleukin-1 $\beta$ gene expression in enteric smooth muscle cells. Gastroenterology 1993;104:A534. (Abst)

33. Khan I, Collins SM. Interleukin-1 $\beta$ induces the expression of interleukin-6 in intestinal smooth muscle cells. Gastroenterology 1995; 108:1720-8.

34. Hogaboam CM, Snider DP, Collins SM. Activation of T lymphocytes by syngeneic murine intestinal smooth muscle cells. Gastroenterology 1996;110:1456-66.

35. Goebels N, Michaelis D, Wekerle H, Hohfeld R. Human myoblasts as antigen presenting cells. J Immunol 1992;149:661-7.

36. Hart MN, Waldschmidt MM, Hanley-Hyde JH, Moore SA, Kemp JD, Schelper RL. Brain microvascular smooth muscle expresses class Il antigens. J Immunol 1987;138:2960-3.

37. Blennerhassett MG, Catallo D. Dexamethasone blocks vascular leakage, but not endothelial activation, in smooth muscle of inflamed rat jejunum. Gastroenterology 1993;104:A670. (Abst)

38. Isgar B, Harman M, Kaye MD, Whorwell PJ. Symptoms of irritable bowel syndrome in ulcerative colitis in remission. Gut 1983;24:190-2.

39. Rao SSC, Read NW, Stobart JAH, Haynes WG, Benjamin S, Holdsworth CD. Anorectal contractility under basal conditions and during rectal infusion of saline in ulcerative colitis. Gut 1988;29:769-77.

40. Barbara G, Vallance BA, Collins SM. Intestinal and colonic muscle dysfunction in an animal model of post-infectious irritable bowel. Gastroenterology 1995;108:A567. (Abst)

41. Beasley D, Cohen RA, Levinsky NG. Interleukin-1 inhibits contraction of vascular smooth muscle. J Clin Invest 1989;83:331-5.

42. Collins SM, Hurst SM, Main C, Stanley E, Khan I, Blennerhassett $\mathrm{P}$, Swain M. Effect of inflammation of enteric nerves. Cytokineinduced changes in neurotransmitter content and release. Ann NY Acad Sci 1992;664:415-24. 


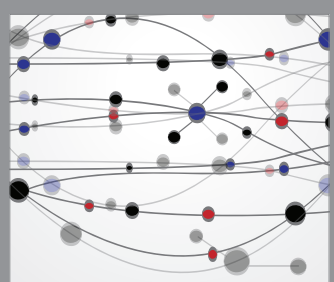

The Scientific World Journal
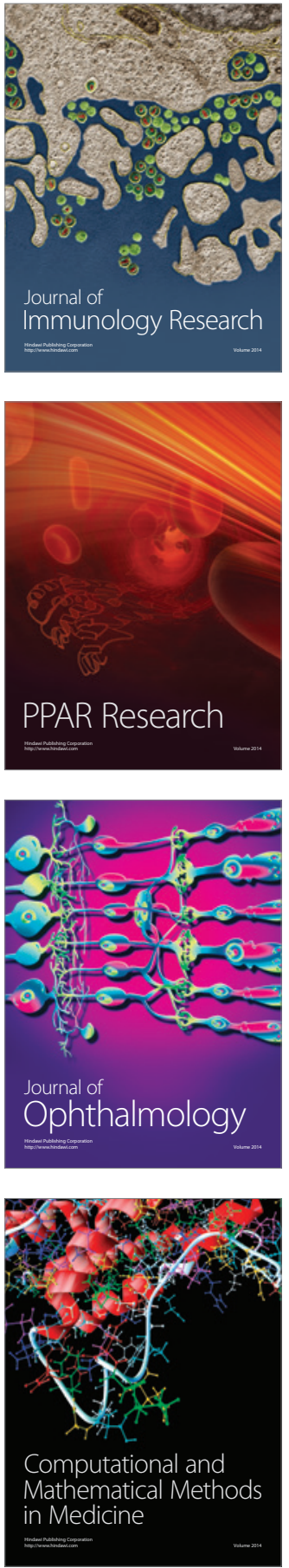

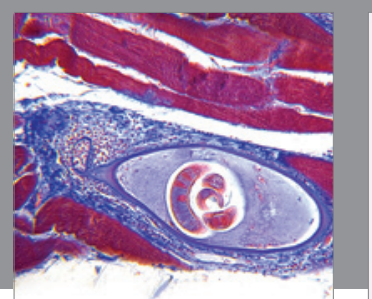

Gastroenterology Research and Practice

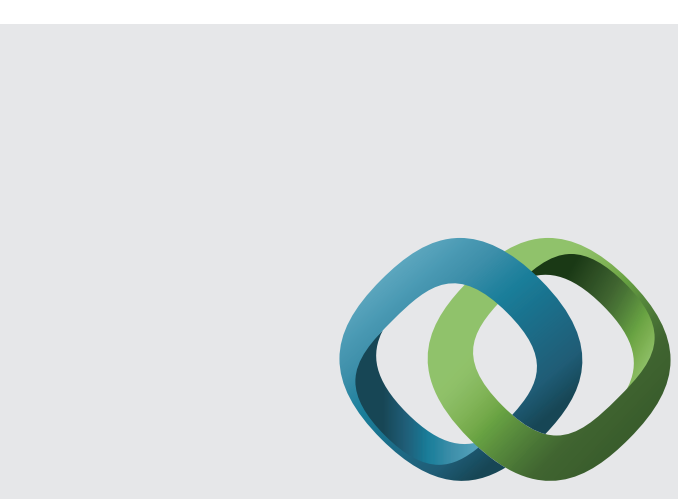

\section{Hindawi}

Submit your manuscripts at

http://www.hindawi.com
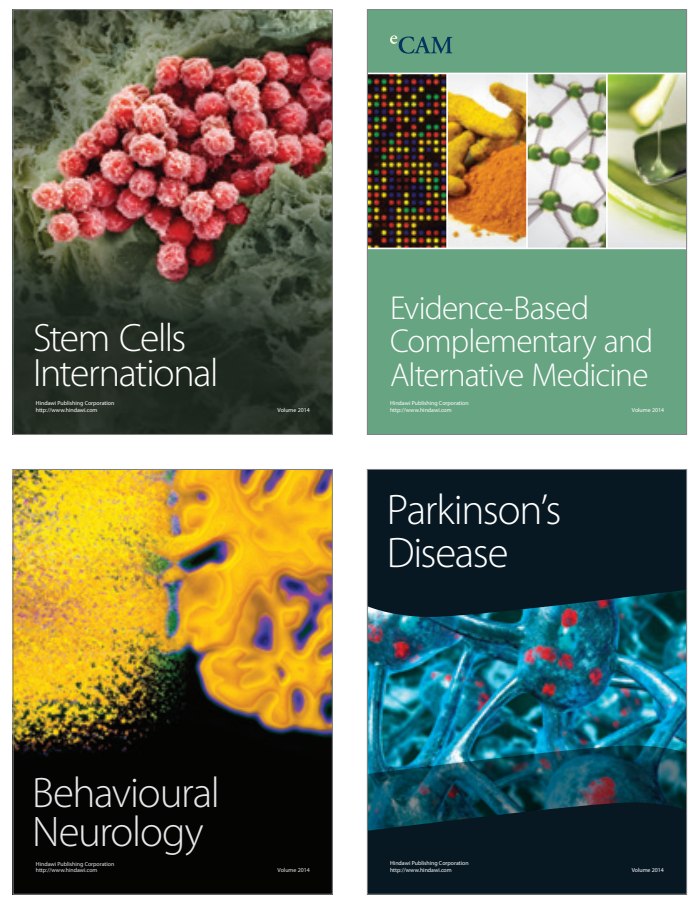
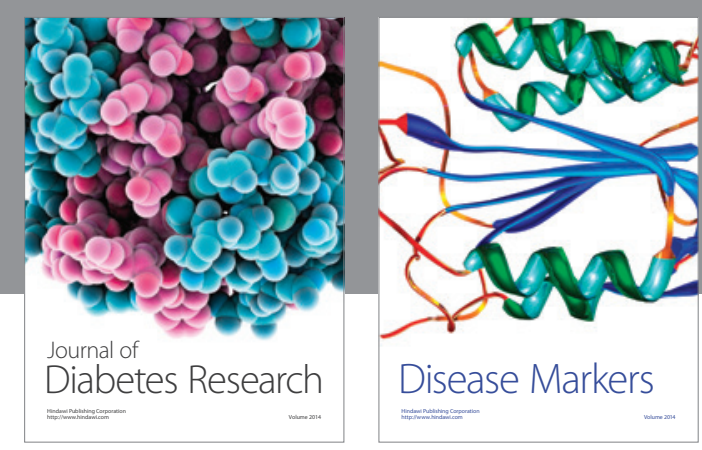

Disease Markers
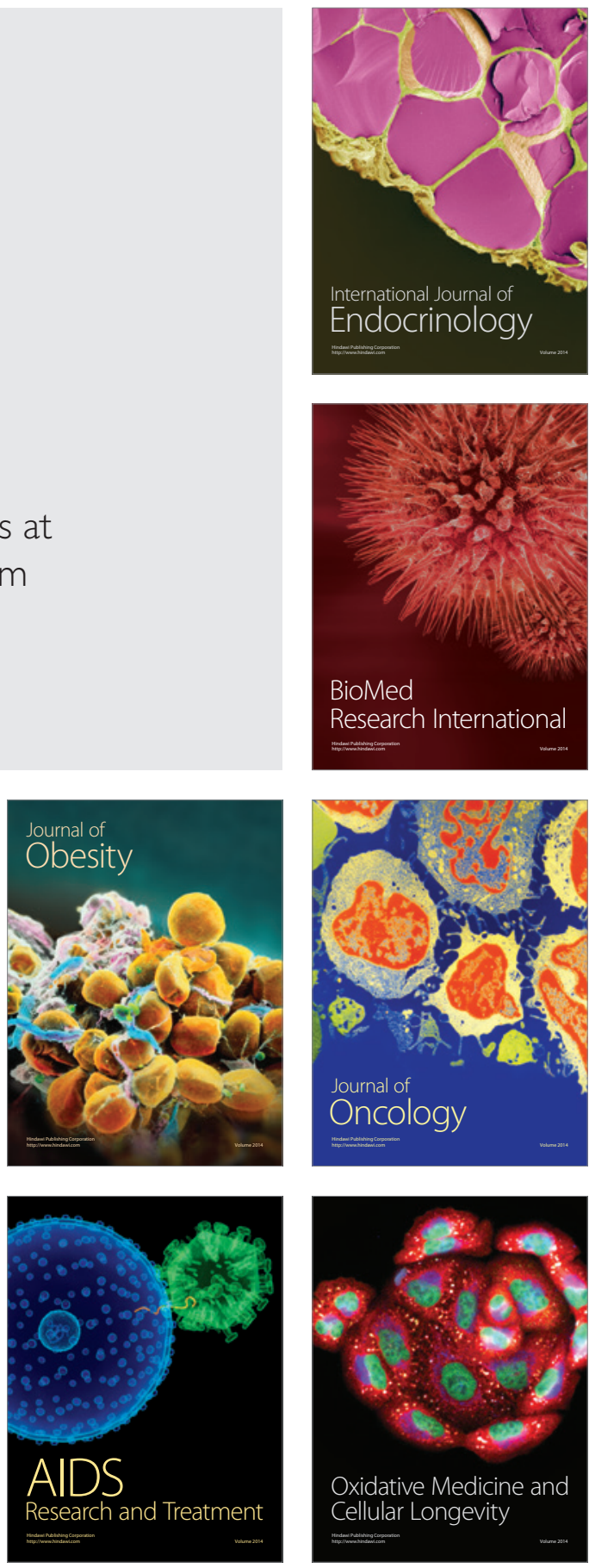